\title{
Revealing Motives And Language Behavior in a Suicide Note
}

\author{
Ilzam Mahfudurido \\ zamiero@yahoo.com \\ Fakultas Ilmu Budaya Universitas Jember
}

Received : 31 December 2017; Accepted : 14 March 2019

URL : $\quad$ http://ejournal.iainpalopo.ac.id/index.php/ideas

\begin{abstract}
Suicide note, one of noteworthy evidences in forensic linguistics, may inform the suicidal behavior of the notewriter, such as the emotional aspects, messages, expectations, motives, and its genuinity. In this article, words, phrases, and sentences employed in a suicide note left by a married young lady were analyzed using lexical semantics, pragmatic semantics, and relevance theory to uncover messages and underlying motives. The procedures began with tabulating and categorizing the words based on their part of speech to see their prominent linguistic features and conducting twofold analysis, namely lexical semantic analysis to find notewriter's messages and pragmatic semantic analysis and relevance theory to find the underlying motive. The results of lexical semantic analysis showed that the notewriter left a couple of messages like apologies and requests but in an assertive mode to be carried out by the abandoned parties, while the results of pragmatic semantics analysis and relevance theory showed that the motive of the suicide was feeling of failure in carrying out her role as a housewife. Patriarchal culture that puts women in charge of serving the family is also presumably to take part in encouraging the suicide.
\end{abstract}

Keywords: Suicide Note, Underlying Content, and Motives

As an interdisciplinary discipline, forensic linguistics involves some other branches of linguistics such as phonology, syntax, semantics, and pragmatics. Even stylistics and discourse analysis are also employed to have further analysis to find answers to cases of legal action involving language. In forensic linguistics, pragmatics plays a prominent role in uncovering implicit meanings and motives owned by parties involved in a legal action. Grice (in Wijana, 1996) states that a speech can imply a proposition that is not part of the speech concerned so-called implicature. In short, there are possibly illocutionary acts needing to be revealed other than its locutionary act in certain speech act. Therefore, in forensic linguistics, pragmatics will uncover certain 
purposes behind a legal text. Linguistic evidence and the outcome of the analysis from a forensic text are of importance because both will greatly help uncover legal actions involving language, or contribute to finding the motives behind it.

There seems to be a trend of employing forensic linguistics recently in Indonesia along with the increasing number of legal actions involving language. Even cultural value may be used as an additional analytical tool, if needed, since human behavior is strongly influenced by the culture where one lives in (Basmin, 2012). One of the common linguistic evidences under investigation of forensic linguistics is a written note made by a suicide victim before committing suicide or so-called a suicide note.

Sometimes suicides are preceded by the abandonment of a note left by the suicide victim before committing the action. This suicide note is very crucial as the onset of the investigation to reveal its content and motive (Richardson \& Breyfogle, 1947), to find out the psychological state of the suicide victim (O'Donnel et al, 1993), and to find out the authenticity of the writing (Basim, 2012). In general, this suicide note is handwritten on a piece of paper, but recently teens put their suicide attempts live-stream and the action inspires others with this new model (Burke, 2017).

Each suicide note left by the suicide victim varies in language styles, dictions, content, and motives, but these notes often have some similarities in move structure and content (Basim, 2012). Some of the linguistic features commonly found in many suicide notes are noun references referring to close-by people and objects and also verbs that can likely convey more the suicide victim's feelings and thoughts (Jones \& Bennel, 2001). All types of suicide notes are pivotal evidences that may enclose certain contents and motives of a suicide. To some cases, authorship analysis is also carried out to find out whether the letter was written by the suicide victim himself (genuine) or by someone else (fabricated) for covering up the action. The aforementioned phenomena are of great significance in suicide-related studies such as forensic linguistic, forensic psychology, or criminology especially to uncover psychological states, hidden contents, motives, or author identification behind a suicide act (Silverman, 2006).

Various approaches to suicide note studies have been exploited, such as analyzing the tone and pattern of words in suicide notes (Aydin \& Dilbilim, 2015), verifying the authenticity of suicide notes using a text analysis program (Malini \& Tan, 2016; Basim, 2012), and using forensic semantics in the analysis of suicide notes (Sudjana \& Fitri, 2013; Alfian, 2018). Analyzing a suicide note to uncover its contents, Alfian (2018) found that the suicide victim used a number of positive and negative adjectives to show the deepest emotional outbursts that he could not bear and ultimately became the suicide motive. Sudjana and Fitri (2013), analyzing a suicide note of an international artist, also found the use of negative phrases and clauses and those phrases collocated with mental states such as depression, regret, and discomfort. They also found a number of metaphors and ambiguous words that represent the suicide victim's psychological state. All of these studies used language as an entry point to analyze suicide notes by looking at tones and patterns, adjectives, semantic-pragmatic relevance, and text analysis programs. However, to date, just a few forensic linguistics studies have been conducted in Indonesia, especially regarding suicide note from its linguistic point of view. Hence, 
it is of great interest and significance that this type of study be conducted to enrich wider perspective on forensic studies. This paper also took cultural aspects to see if any possible relation between the motives and the cultural value within the suicide victim's community.

\section{Method}

A suicide note left by the suicide victim and published in one of the national online media was taken as the object of the study. Words, phrases, and sentences indicated to reveal its contents and show the suicide motives were carefully observed. The stages of the analysis were as follows:

1. documenting the suicide note published in a national online media;

2. breaking down the text to isolate any lexicon potentially giving clues of its contents and motives, calculating their frequencies, and tabulating them based on their parts of speech;

3. highlighting their prominent linguistic features;

4. interpreting the findings based on semantic-lexical, semantic-pragmatic, and relevance theories to get the contents and motives

\section{Results and Discussion}

This study elaborates the findings and discussion all together. The tabulation of parts of speech found in the suicide note was carried out manually considering its length which was only 141 words. The findings were then synchronized with phrases, sentences and contexts as the basis of the analysis to reveal the contents and motives.

The suicide note in this study was written by a young Indonesian housewife who committed suicide in Jeneponto, South Sulawesi Indonesia in December 2017. The police concluded her death as a suicide due to no sign of physical violence was identified, and the police also found a suicide note nearby the crime scene (Yamananda, 2017). The suicide note was addressed specifically to her husband.

\section{Semantic-Lexical Analysis}

Prior to the discussion of how to find the content in the suicide note using a semantic-lexical approach, the following describes parts of speech that potentially lead to the content of the suicide note.

Table 1. Parts of speech in the suicide note

\begin{tabular}{lclc}
\hline $\begin{array}{l}\text { Parts of } \\
\text { Speech }\end{array}$ & Total & Note & Frequency \\
\hline Subject & $18(29.6 \%)$ & a. First Person Singular: I/Aku & 9 \\
Pronoun & & b. Second Person Singular: & \\
& & You/Kamu & 8 \\
& & c. First Person Plural: We/Kita & 1 \\
\hline
\end{tabular}




\begin{tabular}{|c|c|c|c|}
\hline Object & $7(11.5 \%)$ & d. First Person Singular: Me/Aku & 4 \\
\hline \multirow[t]{3}{*}{ Pronoun } & & e. Second & \\
\hline & & You/Kamu & 2 \\
\hline & & f. First Person Plural: Us/Kita & 1 \\
\hline Concrete & $14(22.9 \%)$ & & 14 \\
\hline \multicolumn{4}{|l|}{ Noun } \\
\hline Verb & $18(29.6 \%) ?$ & Active Verb & 18 \\
\hline Adjective & $2(3.3 \%) ?$ & Negative Adjective & 2 \\
\hline Adverb & $2(3.3 \%) ?$ & Manner & 2 \\
\hline TOTAL & $61(100 \%)$ & & 61 \\
\hline
\end{tabular}

The previous study on suicide note using semantic-lexical theory found two frequently used linguistic features; pronouns and verbs. These two parts of speech are believed to be able to convey more on the suicide victim's psychological state (Jones \& Bennel, 2001). Alfian (2018) discovered that suicide note used numerous negative adjectives as the deepest emotional outbursts of the suicide victim. In line with some previous studies, Table 1 showed similar findings that the data obtained in this suicide note also showed pronouns and verbs dominating parts of speech. The difference compared to the previous studies is the lesser use of adjectives found in this study. The reason is that the sentence patterns used by the suicide victim in her note were mostly imperative sentences, such as direct orders or assertive-mode requests. The nature of imperative sentence is that, when written out like in suicide note, it does not have a readily identifiable subject. The subject is actually implied or elliptical, meaning that the verb refers directly back to the subject. In other words, the writer assumes they have their subject's attention. Noun also dominates this suicide note showing people and objects around the suicide victim's life.

The first semantic-lexical analysis deals with the use of adjectives and adverbs. In this suicide note a couple of adjectives and adverbs of manner were found as follows:

a. ...yang membuat kamu marah../that makes you angry (Sentence 6)

b. ...kamu jangan sedih/... don't be sad (Sentence 10)

a. Aku mohon maaf yang sebesar-besarnya./I deeply apologize. (Sentence 5)

d. ...kamu jaga diri baik-baik/...take good care of yourself (Sentence 15)

In general, these adjectives and adverbs of manner form negative meanings. The words 'marah/angry' and 'sedih/sad' show negative emotional involvement of the suicide victim, while 'yang sebesar-besarnya/deeply' and 'baik-baik/good', both have positive meaning but they are used in negative context. The adjectives and adverbs of manner function as an indirect recognition of failure and inability of the suicide victim to meet her husband's expectations, and also her wishes to her husband after her death. Alfian (2018) said that the adjectives used by the suicide victims in suicide notes 
illustrated their psychological state.

The second semantic-lexical analysis is on the use of person pronouns as shown in table 1. The data show that the use of first person subject pronouns are as many as 18 times with the following distribution: 9 first person singular (Aku/I), 8 second person singular (Kamu/You), and 1 first person plural (Kita/We), while person object pronouns are as many as 7 times with the following distributions: 4 first person singular (Aku/I), 2 second person singular (Kamu/You), and 1 first person plural (Kita/Us). Here are some examples of sentences containing the use of subject and object pronouns:
a. Aku duluan ya../ I (go) first ...(Sentence 3)
b. Aku mohon maaf yang sebesar-besarnya../I deeply apologize..(Sentence 5)
c. ...aku lakukan ke kamu /... I did it to you (Sentence 5)
d. Aku minta kamu kuburkan aku.../I want you to bury me ...(Sentence 12)
e. Kamu cari istri yang lebih.../(You) look for a better wife...(Sentence 11)
f. Kamu jangan sedih ya./(You) don't be sad (Sentence 10)

A number of active person pronouns focusing on intense involvement of emotions, intentions, willingness, decisions, and suicidal actions dominate this suicide note. The suicide victim places herself as an active doer responsible for her actions and do not place or blame others for it. Hermann (2003) and Weintraub (2003) stated that suicide notes that exploit the first single person pronoun (I) indicated that the actions were strongly carried out on the suicide victims' own initiative rather than on the pressure of others or groups. In the context of apology (sentence 5) for example, the suicide victim uses active construction with the subject I as the responsible party for apologizing. The suicide victim puts herself as the person taking the initiative to apologize. This implies that the suicide claim herself as the person responsible for all the problems. In Indonesian social context, usually the guilty person initiates the apology.

The third semantic-lexical analysis focuses on the verb use. In this suicide note, 18 active verbs were used. The suicide victim uses active voice in almost the sentence she makes with the intention of showing that she has the sense of power and a great desire for her last request and at the same time an acknowledgment of her failure in satisfying her husband. Roubidoux (2012) explains that suicide victims who use active sentences in writing suicide notes show their courage or firmness about what they feel or want.

\section{Semantic-Pragmatic Analysis and Relevance Theory}

In terms of the sentence type used, the suicide victim uses expressive, declarative, and direct sentences. The purpose of using these sentences is to minimize the debate about the suicide victim's decision, for example who is guilty most and why the action happened. The suicide victim firmly places herself responsible for the decision she makes without having to blame others. As for the sentence structure used, some 
sentences mean direct commands, one command sentence uses politeness marker, and one request marker as seen below:

a. Kamu jangan sedih ya../(You) don't be sad..(Sentence 10)

b. Kamu jangan tinggalkan rumah ini.../(You) don't leave this house ... (Sentence 13)

c. Kamu nggak usah mandiin jenazah aku..._You don't have to bathe my body ... (Sentence 15)

d. mohon kamu cari istri yang lebih dari aku./beg you look for a better wife than me..(Sentence 11)

e. Aku minta kamu kuburkan aku.../I want you to bury me ... (Sentence 12)

In sentence 11 and 12, both are request types, but in context they are assertive in mode as no nuance of negotiations with the suicide victim is found. They indicate strong request of the suicide victim to the intended party and also show the suicide victim's power to govern the intended party as a great desire so that her expectations and wishes are fulfilled for the sake of herself and her husband after her death.

In following sentences, two expressions of apology were written by the suicide victim:

a. Aku mohon maaf yang sebesar-besarnya/I deeply apologize (Sentence 5)

b. Aku juga ucapkan minta maaf kepada semua/I also apologize to everyone (Sentence 8)

The structure of both sentences is in active forms with active person pronouns indicating the powerful voice of the suicide victim in determining her decision. This is in accordance with Rubidoux's findings (2012) that the suicide victims will write their apologies in suicide notes using active voice rather than passive voice as an expression of their powerful will.

Some studies that use pragmatic approaches in examining suicide notes classify four motives of suicide victims to take such personal actions, namely: the disease suffered by the suicide victim, feeling very burdened on something, blaming others who play a major role in suicide victims' decisions, and despair (Prokopyefa , 2013). Looking at the context of the suicide note in this study, the motive for suicide was because of being burdened by something. The following excerpt leads what the suicide victim feels of being burdened with her household:

"Aku mohon maaf yang sebesar-besarnya atas segala dosa yang telah aku lakukan ke kamu selama ini. Yang membuat kamu marah... dan lain sebagainya..." (I deeply apologize for all the mistakes I have committed to you so far. That made you angry ... and so on ... )

The excerpt above implies that the suicide victim places herself as the responsible 
party for what happened in the family. The problems she caused made her husband angry and likely took other unstated violence as implied in phrases "and so on". Her weaknesses were believed to be the source of problems in the family and she took it as a failure to meet the expectations of the people she loved. Hence, her guilt is believed to be the driving force to commit suicide without blaming others. The strength of this drive is reflected in the structure of the language used in the form of active sentences with the first person subject pronouns and are declarative, decisive, and directly to the point.

The next point to discuss is that some messages and expectations of the suicide victim can lead us to the suicide motives. Due to the inability of the suicide victim to comply with her husband's expectations, the suicide victim then expressed her statement in an assertive-mood wish. Here is the excerpt:

"dan mohon kamu cari istri yang lebih dari aku yang bisa ngurus kamu terus yang tidak membuat seperti aku."/"and beg you to look for a better wife who can take care of you and who doesn't cause troubles like me."

In particular, this request inferred a reaffirmation of the suicide victim's failure so that the suicide victim advised her husband to find a better wife who could satisfy the husband's expectations, not like her who was incapable of carrying out her responsibilities as a wife. Furthermore, the suicide victim conveyed several commands using the word "jangan/don't" or assertive-mode request that sound more as a command as in the following:

a. ...kamu jangan sedih ya.../(you) don't be sad ...(Sentence 10)

b. ... kamu jangan tinggalkan rumah ini.../(you) don't leave this house ... (Sentence 13)

c. ... kamu ngk usah mandiin jenazah aku.../(you) don't need to bathe my body ...(Sentence 15)

Along with some requests, the suicide victim used some declarative sentences but they tend to mean orders:

a. .. aku minta kamu kuburkan aku di samping rumah kita.../I ask you to bury me next to our house ... (Sentence 12)

b. ... aku ingin kamu dan istrimu tinggal di rumah ini.../I want you and your wife to stay in this house ...(Sentence 14)

A very critical point for further discussion is at the possibility of the violence in the family. Alimuddin (2014) stated that domestic violence has two dimensions, namely physical violence, such as beating and slapping, and psychological violence, such as insulting, rude speaking, or threatening. The excerpt of the clause "..yang membuat kamu marah... dan lain sebagainya..." (that makes you angry ... and so on ...) implies 
that there has been psychological violence experienced by the suicide victim. Anger is often expressed using a rude tone of voice. Furthermore, the phrase "dan lain sebagainya (and so on)" indicates that anger is not the only violence experienced by suicide victim. There could be any other psychological or physical violence the victim did not not mention in her note. Setyono (2018) stated that women have always been the victimized party in family violence in Indonesia. In Indonesian culture that holds patriarchal culture, the responsibility of serving family members lies on wife's hand and failure to do so will cause her at blame. It likely contributed more to the suicide victim's burden in present case. A wife, in patriarchal culture, is fully responsible to her husband and her husband has control over her and the rest of the family. Hence, when problems occur in the family, the wife will be the first to be responsible for. All the explanations above converge in a conclusion that the suicide victim's feeling of being failed to accomplish her role as a wife and the community value of culture of wife's responsibility in the family contributes to the driving force to commit suicide.

\section{Conclusion}

The language used in suicide notes has a pivotal role in determining at least two things; its content and motives, and the authorship of the writing. Semantic-lexical and semantic-pragmatic approaches are very helpful in determining the content and the motives of the suicide because both approaches will reveal its linguistic features such as words chosen, clause and sentence patterns, and inter-sentential relations. The relevance theory, on the other hand, is used as a further step in determining the motives of the suicide victim by looking at the relationships between sentences, story lines, and intentions implied behind the words and sentences used. In short, to get the content and motive in a suicide note two steps of analysis should be taken: the first, to see the surface structure through the linguistic features used, and the second, to observe the deep structure to get underlying meanings behind the text.

The present study found that the suicide victim conveyed some assertive requests and commands to her husband to carry out after her death for the goodness of her and her husband. The suicide note also implied the strong desire of the suicide victim to commit suicide because of burden of failure in carrying out her responsibilities as a wife that did not satisfy her husband. She placed herself as the one responsible for the problems and the actions without blaming other party. The linguistic features chosen such as the subject of the sentence and the structure of the active sentence showed her powerful will. In addition, patriarchal culture that a wife is responsible for what happened in the family also likely contributed to the victim's decisions implied by her apologies for the failure and her husband's anger. 


\section{References}

Alfiyan, R. (2018). Meanings in a Suicide Note: An Analysis of Linguistics Pragmatics in Nusadi's Suicide Note. Diakses dari https://www.researchgate.net/publication/323150837

Alimuddin. (2014). Penyelesaian Kasus KDRT (Kekerasan dalam Rumah Tangga) di Pengadilan Agama. Bandung: Mandar Maju.

Aydin, L. \& Dilbilim, A. (2015). An Analysis of Adjectives Used in Suicide Notes in Terms of Positivity/Negativity/Neutrality. Diakses dari http://www.academia.edu/download/37563443/Dilbilimde_Arastirma_Projeleri__final.docx

Basim, Y, J. (2012). Author Attribution in Suicide Notes: Evidence from Applied Linguistics. $\begin{array}{llll}\text { Comparative } & \text { Legilinguistics, } & \text { Diakses dari }\end{array}$ https://www.researchgate.net/publication/323223150

Burke, M. (2017, Jan 25). Miami Teen Commits Suicide in Two-Hour Long Facebook Live Video, the Third in as Many Weeks. NY Daily News. Diakses dari http://www.nydailynews.com

Hermann, M. G. (2003). Assessing Leadership Style. The Psychological Assessment of Political Leaders. Ed. Post, J. M. Ann Arbor: University of Michigan Press. 178-212.

Jones, N. \& Bennel, C. (2007). The Development and Validation of Statistical Predication Rules for Discriminating between Genuine and Simulated Suicide Notes. Archives of Suicide Research, 11, 219-233.

Malini, N. L. N. S. \& Tan, V. (2016). Forensic Linguistics Analysis of Virginia Woolf's Suicide Notes. International Journal of Education , 9 (1), 53-58.

O’Donnell, I., Farmer R., \& Catalan J. (1993). Suicide Notes. British Journal of Psychiatry, 1 (163), 45-48.

Prokofyeva, T. (2013). Language Use in Two Types of Suicide Texts. Department of Culture and Communication. Linköping University. Tesis Tidak Dipublikasikan.

Richardson O. \& Breyfogle, H. S. (1947). Problems of Proof in Distinguishing Suicide from Accident. The Yale Law Journal, 56 (3), 482-508.

Roubidoux, S. M. (2012). Linguistic Manifestations of Power in Suicide Notes: An Investigation of Personal Pronouns. Department of English. The University of Wisconsin Oshkosh. Tesis Tidak Dipublikasikan. 
IDEAS, Vol. 7, No. 1, June 2019

ISSN 2338-4778 (Print) ISSN 2548-4192 (Online)

Setyono, B. (2018). The Portrayal of Women in Nationally-Endorsed Engliah as a Foreign Language (EFL) Textbooks for Senior High School Students in Indonesia. Sexuality and Culture. Springer. https://doi.org/10.1007/s12119-018-9526-2.

Silverman, M. M. (2006). The language of suicidology. Suicide and Life-Threatening Behavior, 36 (5), 519-532.

Sudjana, E. T., \& Fitri, N. (2013). Kurt Cobain's Suicide Note Case: Forensic Linguistic Profiling Analysis. International Journal of Criminology and Sociological Theory, 6 (4), 217-227.

Weintraub, W. (20013). Verbal Behavior and Personality Assessment. The Psychological Assessment of Political Leaders. Ed. Post, J. M. Ann Arbor: University of Michigan Press.137-53.

Wijana, C. A. (2016, Feb 11). One Year on, Investigation into UI Student Death Stalled. The Jakarta Post. Diakses dari http://www.thejakartapost.com

Yamananda, I. (2017, Des 3). Sebelum Tewas Gantung Diri, Wanita Muda ini Tulis Surat untuk Suaminya! Isinya Mengharukan. Tribunenews. Diakses dari http://style.tribunnews.com 